\title{
The use of movement games in the educational process (on the example of physical education classes in primary school)
}

\author{
Aslonova Malohat Akramovna \\ Candidate of Pedagogical Sciences. Associate Professor of Physical Culture, Faculty of Physical \\ Culture, Navoi State Pedagogical Institute. Uzbekistan
}

\begin{abstract}
This article discusses the issues of the place, meaning and role of outdoor games in the physical education of schoolchildren, as well as the use of outdoor games with non-standard tasks at physical culture lessons. The study of the interest of schoolchildren in physical education lessons has been carried out.
\end{abstract}

Key words: outdoor games, physical education, schoolchildren, elementary grades, physical education lesson.

Introduction. The formation of children's health, the full development of their body is one of the main problems in modern society. Younger school age is the period when the foundations of health, harmonious development are laid, motor skills are formed, and the foundation is created for the physical improvement of the child. However, the existing system of school education takes into account only the sanitary and hygienic standards of the living conditions of schoolchildren and leads to the rationing of motor qualities and skills.

Game activity, as a means of teaching and improving the motor fitness of primary schoolchildren, is the most productive direction of the educational process in the modern methodology of physical education. This circumstance is due to the fact that the peculiarities of the development and functioning of the main systems of the body of young children to the greatest extent, are adapted precisely to play activities outdoor games, creating an atmosphere of joy, make the most effective complex solution of health-improving, educational and upbringing tasks. Active movements, conditioned by the content of the game, evoke positive emotions in children and enhance all physiological processes.

The educational value of the game, its comprehensive influence on the development of students can hardly be overestimated. Play is organically inherent in childhood and, with skillful guidance from adults, can work wonders. A playful person can make a hardworking one, a dunno - a knowledgeable, inept craftsman.

Like a magic wand, the game can change the attitude of students to what they sometimes think is too ordinary, boring, boring.

The game will help the teacher to rally the class, to include in the active activities of students withdrawn and shy. In games, conscious discipline is brought up, students are taught to observe the rules, fairness, the ability to control their actions, correctly and objectively evaluate the actions of others. Play for students is an important means of self-expression, a test of strength.

In games, the teacher can better get to know his students, their character, habits, organizational skills, creative possibilities, which will allow him to find the most correct ways of influencing each of the students and, which is also very important, the games bring the teacher closer to the students, help to establish more close contact. 
In the play activity of children, two very important factors are objectively combined: on the one hand, children are involved in practical activities, develop physically, get used to acting independently; on the other hand, they receive moral and aesthetic satisfaction from this activity, deepen their knowledge of their environment. All this contributes to the education of the individual as a whole. Thus, play is one of the complex means of education: it is aimed at all-round physical fitness (through direct mastering of the basics of movement and complex actions in the changing conditions of collective activity), improving the functions of the body, character traits of the players.

Therefore, I believe that the topic is relevant.

In this regard, the purpose of the work is determined: to study the methodology of conducting educational games (for example, outdoor games) for primary school age for further use in physical education lessons.

Object - educational process in physical education.

Subject - a methodology for conducting educational games for children of primary school age at physical education lessons.

Hypothesis: I suppose that the use of specially selected outdoor games will allow us to further interest young schoolchildren in physical education lessons, to form practical skills for physical education in the middle level. In accordance with the goal set and the topic and problem put forward, I have defined the tasks of this work:

1. To study the anatomical and physiological characteristics of the development of children of primary school age.

2. Consider the methodology for conducting educational games at primary school age.

3. To select and systematize outdoor games for schoolchildren in accordance with the sections of the general educational program "Physical culture".

Methods used: analysis of the state of problems, pedagogical observation, conversations

Outdoor games are an important means of education, one of the most beloved and useful activities of primary school students. They are based on physical exercises, movements, during the implementation of which students overcome a number of obstacles, strive to achieve a certain, predetermined goal. Outdoor games are the best medicine for students against motor "hunger" - physical inactivity. Many of them have existed since time immemorial and are passed down from generation to generation. Time makes changes in the plots of some games, fills them with new content, reflecting modern life. Games are enriched, improved, many complicated variants are created, but their motor basis remains unchanged. The most important advantage of outdoor games is that they exhaust all types of natural human movements: walking, running, jumping, wrestling, climbing, throwing, throwing, and catching, exercise with objects.

Outdoor games have a sufficient advantage over other means of physical culture and are at the highest level of interests of children, therefore, the use of predominantly play means in the lesson will contribute to the optimal solution of the problems of physical education.

Games are the most universal and irreplaceable means of physical education for students. In pedagogical practice, collective and individual outdoor games are used, as well as games leading to sports activities. 
Collective outdoor games are games in which both small groups of participants and whole classes or sports sections participate simultaneously, and in some cases, a significantly larger number of players.

Individual (solitary) outdoor games are usually created and organized by children. In such games, everyone can outline their plans, establish conditions and rules that are interesting for themselves, and, if desired, change them. On a personal request, paths are also chosen for the implementation of the planned actions.

Games leading to sports activities are systematically organized outdoor games that require stable conditions for holding and contribute to the successful mastering by students of elements of sports technology and the simplest tactical actions in certain sports.

Outdoor games are one of the aids in sports. Such games are also used by teachers who conduct extracurricular and extracurricular work on physical culture and sports with children and adolescents to organize their leisure time.

The activity of various analyzers, clearly expressed in outdoor games, creates favorable opportunities for training the functions of the cerebral cortex, for the formation of new temporary positive and negative connections, and an increase in the mobility of nervous processes. This has a positive effect on the assimilation of individual sports and technical techniques and their combinations, creates the preconditions for a more successful mastery of tactical actions, and also confirms that outdoor games contribute to the upbringing of will, endurance, discipline and other qualities necessary for everyone to achieve success in sports. ...

Play develops and strengthens the major muscle groups and thus improves health. The acquired motor experience and good physical fitness create the necessary prerequisites for subsequent sports activity.

A characteristic feature of outdoor games is not only the richness and variety of movements, but also the freedom to use them in a variety of game situations, which creates great opportunities for the management of initiative and creativity. Outdoor games have a pronounced emotional character. In playing, the student experiences the joy of exerting the physical and mental strength necessary to succeed.

There are several classifications of outdoor games. Traditionally, games are distinguished by the lack of inventory, the number of participants, the degree of intensity and specificity of physical fitness, the presence of the host, the venue, the elements of the space markup, the scoring system, the game preludes and punishment, the general plot, etc. ... Considering outdoor games based on the organization of the players, the following can be distinguished:

a) without dividing the team into teams (games based on the simplest relationships between participants);

b) with the division of the team into teams (games aimed at fostering collective action).

Games can run in various combinations:

a) games where active combat takes place;

b) games, without contact with an opponent;

c) relay games, in which the actions of each participant are equally directed, are associated with the performance of individual tasks.

Games can be divided into outdoor games and sports games (basketball, hockey, football, etc.). 
The classification of outdoor games can be considered according to the following criteria:

1. By age

2. By content (simple, elementary, complex, with rules and games with elements of sports games);

3. By the predominant type of movement (games with running, jumping, climbing and crawling, rolling, throwing and catching, throwing);

4. By physical qualities (games for the development of agility, speed, strength, endurance, flexibility);

5. By sports (games leading to basketball, badminton, football, hockey; games with skis and skiing, in the water, sledging and sledging, on the ground);

6. On the basis of the relationship of the players (games with contact with the enemy and games without contact);

7. By plot (plot and plotless);

8. By organizational form (for physical education, outdoor activities, physical culture and health improvement work);

9. By mobility (low, medium and high intensity mobility);

10. At the place of employment (for a sports hall, sports ground; for terrain, premises);

11. By the way the players are organized: team and non-team (with division into teams, relay games; games without team division - each player acts independently in accordance with the rules of the games).

One of the main tasks of physical education is the development and improvement of the physical qualities of those involved.

The content orientation of the practical use of game material in physical culture lessons is as follows:

- if the problem of strength development is being solved, then auxiliary and lead games are used, associated with short-term speed-power stresses and the most diverse forms of overcoming the opponent's muscle resistance in direct contact with him. The main content components of such games include various pulling, pushing, holding, pushing, etc. Effective for solving this problem are motor operations with weights available to children, bending, squatting, push-ups, lifting, turning, rotating, running or jumping.

- If the problem of developing the quality of speed is being solved, games should be selected that require instant responses to visual, sound or tactile signals. These games should include physical exercises with periodic accelerations, sudden stops, rapid jerks, instant delays, running short distances in the shortest possible time and other motor acts aimed at deliberately and purposefully getting ahead of the opponent.

- If the task of developing dexterity is being solved, it is necessary to use games that require the manifestation of precise coordination of movements and quick coordination of their actions with teammates, possessing a certain physical dexterity.

- If the problem of endurance development is being solved, it is necessary to find games associated with a large expenditure of strength and energy, with frequent repetitions of compound motional operations or with prolonged continuous motional activity, conditioned by the rules of the applied game. 
The content of an active game is made up of its plot, theme, idea, rules and motional actions. The plot of the game determines the goal of the players' actions, the nature of the development of the game conflict.

It is borrowed from the surrounding reality and figuratively reflects its actions or is created specially, proceeding from the tasks of physical education, in the form of a confrontation scheme, with various interactions of the players.

The plot of the game not only revives the holistic actions of the players, but also gives individual techniques and elements of tactics purposefulness, makes the game exciting.

The rules are mandatory requirements for the participants in the game. They determine the location and movement of players, clarify the nature of behavior, the rights and obligations of the players, determine the methods of playing the game, methods and conditions for taking into account its results.

Motor actions in outdoor games are very diverse. They can be, for example, imitative, imaginative-creative, rhythmic; performed in the form of motor tasks requiring the manifestation of dexterity, speed, strength and other physical qualities. All motor actions can be performed in a wide variety of combinations.

\section{References:}

1. Mirziyoyev Sh. Oliy ta'limda foydalaniladigan nashrlar va axborotlarni uzatishning zamonaviy manbalari. 19 май 2018 й.

2. Akramova Gulbahor Renatovna, Akramova Surayo Renatovna. Pedagogical and psychological conditions of preparing students for social relations on the basis of the development of critical thinking. Psychology and education. Vol. 58 No. 2 (2021): Volume 58 No. 2 (2021). P. 48894902 http://psychologyandeducation.net/pae/index.php/pae/article/view/2886

3. Aminova Feruza Hayitovna. Axiological analysis of socio-aesthetic problems in hadiths An International Multidisciplinary Research Journal 1457-1462, 2020. https://www.indianjournals.com/ijor.aspx ?target=ijor:aca\&volume $=10 \&$ issue $=5 \&$ article $=212$

4. Aminova Feruza Hayitovna. Основные принципы исследовательского обучения в школе 2018 international scientific review of the problems of pedagogy and psychology 19 aprel 2018 https://scientific-conference.com/images/PDF/2018/1/basic-principles.pdf

5. Amonov Ulugmurod Sultonovich. Abdurauf Fitrat is one of the earliest researchers of uzbek folklore. "Academicia” An International Multidisciplinary Research Journal, India. June 2020. 669-673 p. 10.5958/2249-7137.2020.00616.3 https://www.indianjournals.com/ijor.aspx?target=ijor:aca\&volume=10\&issue=6\&article=096

6. Amonov Ulugmurod Sultonovich. Folklore in the works of Abdurauf Fitrat. International scientific journal «Theoretical \& Applied Science», USA. September 30, 2016. 12-15 p. https://www.semanticscholar.org/paper/folklore-in-the-works-of-abdurauf-fitrat amonov/dcc79abce08ba4602c2dc5b5ae3a87b345797d63

7. BuryakovYu.F. The history of non-ferrous metals in Uzbekistan in antiquity and in the Middle Ages. // Materials of the Republican Scientific and Practical Conference. NEVELLAND. - C11.

8. CM: Kuchersky N.I, Astanzaturian G.G. BerdnikovE.A.Navoi. CGA RUZ. F - M 20, OP. 16, units. XP.62, 1. 19. Norma.uz National Database of Legislation, 06.03.2020, No. 07/20/4629/0258) 
9. Eshonkulova Dilafruz Husenkizi. Ways to develop critical thinking in adolescents An International Multidisciplinary Research Journal184-188 2020, https://www.indianjournals.com/ijor.aspx?target=ijor:aca \&volume=10\&issue $=10 \&$ article $=024$

10. Жумаева $Ф$ Р. Использование разных видов текстов в качестве дидактического материала на уроках русского языка. https://cyberleninka.ru/article/n/ispolzovanie-raznyh-vidov-tekstovv-kachestve-didakticheskogo-materiala-na-urokah-russkogo-yazyka

11. Жумаева Ф. Р., Хакимова Н. Х. Формирование языковой и коммуникативной компетенции учащихся при работе над текстом. http://eclss.org/publicationsfordoi/istanbulonline.pdf\#page $=168$

12. Ruziyevna J. F, Baxronovna M. F. Tolerance is the basis for creating a humanistic culture in the world. Academicia: An International Multidisciplinary, 2020. https://www.indianjournals.com/ijor.aspx?target=ijor:aca\&volume=10\&issue $=5 \&$ article= $=254$

13. Khodjieva Farogat Oltievna The Actuality And The Content of Forming Critical Thinking Skills Of Primary School Pupils Psychology and Education Journal 2020. http://psychologyandeducation.net/pae/index.php/pae/article/view/986

14. Muradova Dilfuza Zhurakulovna. 58-60 2020 The formation of communicative competence of pupils primary school. European Science58-60 2020 https://scientificpublication.com/images/pdf/2020/52/european-science-3-52-.pdf

15. Rasulov Jasur Saparovich Effects of training based on neuropedagogy International Scientific Review of the Problems and Prospects of Modern Science and Education 30.08.2018 https://scientific-conference.com/h/sborniki/pedagogicheskie-nauki2/1376-effektyobucheniya.html

16. RizaevS.NavoiyGorno-Metallurgical. - Tashkent: Shark, 2008.- C. 86.

17. Ryziqulova Amina Totliboyevna. The role of national values in ensuring the stability of marriage and family relations in modern uzbek families. ACADEMICIA: An International Multidisciplinary Research Journal 88-93 $2020 \quad$ 10.5958/2249-7137.2020.01126.X. https://saarj.com/wp-content/uploads/ACADEMICIA-OCTOBER-2020-FULL-JOURNAL.pdf.

18. Sattorovna Jamilova Bashorat, Sadriddinovna Nuriddinova Shaxnoza The spiritual description of adults in uzbek children's prose-the place of literary psychologism. Academicia: an international multidisciplinary research journal. Year: 2021, Volume:11, Issue:1

19. See: Batalova I. Gaev Y. Combine, time, fate. Tashkent. Abu Ali Ibn Sina Medical Literature Sina Ali. - C. 57.

20. Shalatonin B.S. "Shadows on the rocks" - T: A. Kadyri, 1999. - C.20.

21. Shamsutdinov R., Мўминов Н.ўзбекистонTarios. -T.: Sharc; 2013. -b. 25.

22. Temirov, Odinaeva Z. CadimgiDipboard Con-metallurgy Tarios. - T.: Yanga ASR Avlodi, 2008. - B.8.

23. Temirov, Odinaeva Z. CadimgiDipboardKon-Metallurgy Tarios. - T.: Yangang ASR Avlodi, 2008. -B. 15

24. Tukmuradova Malika Elmurodovna. Impact of digital education on delivering English lessons An International Multidisciplinary Research Journal1787-1791,2020 https://www.indianjournals.com/ijor.aspx?target=ijor:aca \&volume=10\&issue $=11 \&$ article $=289$

25. Usmanov K. The history of Uzbekistan. - T: "Shark", 2007. - p.64. 
26. Xalilova Ruxsora Raupovna. The Formation Of Professional Speech Of Students In The Learning Process At The University. European Journal of Research and Reflection in Educational Sciences $\quad$ Vol 7. $2019 \quad \underline{\text { http://www.idpublications.org/wp- }}$ content/uploads/2019/09/Full-Paper-THE-FORMATION-OF-PROFESSIONAL-SPEECH-OFSTUDENTS-IN-THE-LEARNING-PROCESS-AT-THE-UNIVERSITY.pdf

27. Абилова Гаухар Оринбековна. On the issue of training highly qualified teachers. International Scientific Review of the Problems and Prospects of Modern Science and Education. 2018 https://scientific-conference.com/h/sborniki/pedagogicheskie-nauki2/952-on-the-issue.html

28. Ахатова Дурдона Актамовна. Didactic Opportunities to Ensure Compliance With The Goal And Content Of Education in The Modernization Process International Scientific Review of the Problems and Prospects of Modern Science and Education12 dekabr 2019 yil https://scientific-conference.com/h/sborniki/pedagogicheskie-nauki2/2071-didakticheskievozmozhnosti.html

29. Ахатова X. А. 2019. Факторы повышения эффективности воспитания гармоничного поколения в образовании International Scientific Review of the Problems and Prospects of Modern Science and Education 12 dekabr 2019 yil. https://scientificconference.com/h/sborniki/pedagogicheskie-nauki2/2070-faktory-povysheniyaeffektivnosti.html

30. Баходир Маъмуров. Акмеологик Ёндашув Асосида Бўлажак Ўқитувчиларда Таълим Жараёнини Лойихалаш Кўникмаларини Ривожлантириш. Том 1 № 1 (2020): Таълим ва инновацион тадқиқотлар. http://interscience.uz/index.php/home/article/view/15

31. Башорат Жамилова, Мохигул Каххорова. Болалар детектив насридаўсмирлар рухияти тасвири. Том 1 № 1 (2020): Таълим ва инновацион тадқиқотлар. http://interscience.uz/index.php/home/article/view/37

32. Лукмонова С.Г. Цифровые образовательные ресурсы в педагогической деятельности [Digital educational resources in teaching] // XXI International scientific review of the problems of philosophy, psychology and pedagogy. https://scientificconference.com/h/sborniki/yuridicheskie-nauki2/2249-media-security-trend.html

33. Махмудов Мэлс. Дидактик Лойихалаш - Замонавий Таълимда Самарадорлик Кафолати. $\begin{array}{lllllll}\text { Том } & 1 & \text { № } & 1 & \text { (2020): } & \text { Таълим } & \text { ва } \\ \text { инновацион тадқиқотлар. }\end{array}$ http://interscience.uz/index.php/home/article/view/14

34. Рўзиева М. Ё. Туркий халқлар фольклорида ранг ифодаловчи сўзлар ва уларнинг семиотик тахлили. Том 1 № 1 (2020): Таълим ва инновацион тадқиқотлар. http://interscience.uz/index.php/home/article/view/34

35. Эльчиева Динара Толубаевна . Формирование познавательного интереса и познавательной активности младших школьников European Science50, 2020 June. https://scientific-publication.com/images/PDF/2020/53/EUROPEAN-SCIENCE-4-53-.pdf 